\title{
VTA, SamTrans Look into Future with Bus Demo
}

\section{SANTA CLARA VALLEY TRANSPORTATION} AUTHORITY (VTA) is a multi-modal transportation organization based in San Jose, California. VTA provides bus and light rail service in Santa Clara County, as well as congestion mitigation, highway improvement projects, and countywide transportation planning. VTA operates an active bus fleet of 423 buses on 69 routes throughout the urbanized area of Santa Clara County.

In February 2000, the California Air Resources Board (CARB) adopted new regulations for transit buses to reduce oxides of nitrogen and particulate matter emissions. As a result, VTA adopted a clean fuels strategy, which includes a zero-emission bus program. The fleet entered into contract with Gillig Corporation and Ballard Power Systems to procure three low-floor fuel cell buses, which were delivered in 2004. VTA is working with the San Mateo County Transit District (SamTrans) to demonstrate these fuel cell buses in revenue service. In addition to complying with the CARB regulations, VTA's goals include testing the viability of emerging cleanfuels technology.

VTA is currently collaborating with the U.S. Department of Energy's (DOE) Hydrogen, Fuel Cells \& Infrastructure Technologies (HFCIT) Program on the evaluation of the three fuel cell buses developed by Ballard and Gillig. VTA will operate the buses in revenue service as part of the two-year demonstration program. During this time, DOE's National Renewable Energy Laboratory (NREL) will collect and analyze performance and operations data.

This evaluation is one of several DOE projects that support the research and development of low- or zero-emission fuel cell power systems and is consistent with the HFCIT Program goal of an industry commercialization decision by 2015. Information gathered during the demonstration will help researchers assess the status of the technology and aid fleets in making informed purchase decisions. Results will also be fed back into the $R \& D$ process to focus future resources, as appropriate.

THE GILLIG BUSES BEING TESTED by VTA/SamTrans are typical in every way - standard seating capacity, wheelchair lift, air conditioning — but they are fueled with hydrogen and propelled by a fuel cell electric drive. Ballard Power Systems supplies the two $150 \mathrm{~kW}$ (300 kW per bus) proton-exchange membrane (PEM) fuel cells, as well as one three-phase

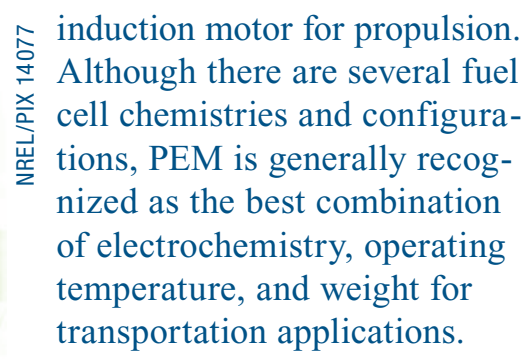

The fuel cell supplies electric current via an inverter to the propulsion motor, which is a proprietary design. This chassismounted, three-phase, induction motor is rated at $225 \mathrm{~kW}$ (369 horsepower). Hydrogen is stored onboard in eleven 5,000-psi cylinders that are located on the roof. These Dynetek Dynecell carbon fiber-wrapped tanks are equipped with many safety features, including pressure release devices, which safely vent the hydrogen in the unlikely event of an accident or fire.

VTA fuels these advanced technology buses at the VTA Cerone Operations Division using a hydrogen fueling station constructed and operated by Air Products \& Chemicals, Inc. The fueling station, which is leased to VTA, consists of a tank that receives and stores hydrogen in liquid form. Hydrogen is compressed to $6,000 \mathrm{psi}$ and vaporized for secondary storage in a pressurized tank cascade. Air Product's unique liquid compression system enables fast filling of fuel cell buses. A fueling island dispenses pressurized gaseous hydrogen to the fuel cell buses. This facility is monitored remotely by Air Products and is equipped with a variety of sensors and alarms.

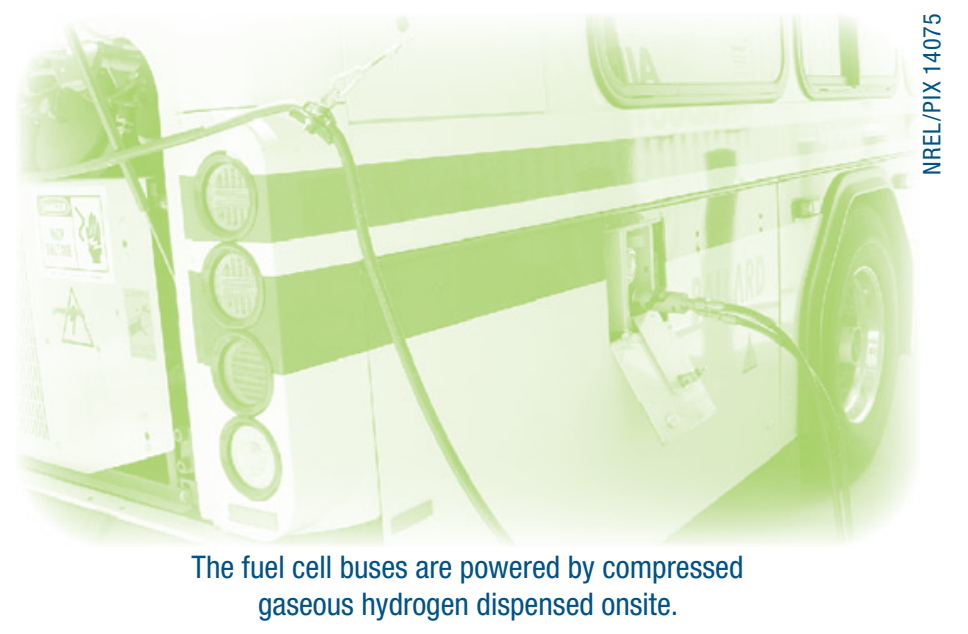




\section{VTA FUEL CELL BUS FACTS}

\begin{tabular}{|c|c|}
\hline Bus Chassis & Gillig, low-floor \\
\hline Model Year & 2004 \\
\hline Length/Width/Height & $40 \mathrm{ft} / 102 \mathrm{in} / 144 \mathrm{in}$ \\
\hline GVWR/Curb Weight & $40,600 \mathrm{lb} / 34,100 \mathrm{lb}$ \\
\hline Seats & $\begin{array}{l}37 \text { passenger seats } \\
29 \text { seats with two wheelchair spaces }\end{array}$ \\
\hline Wheel Base & 284 in \\
\hline Service & Extra revenue transit service \\
\hline Drive System & $\begin{array}{l}\text { Fuel cell powerplant, inverter, one electric } \\
\text { propulsion motor, six-speed transmission }\end{array}$ \\
\hline Powerplant & $\begin{array}{l}\text { Two Ballard Power Systems PEM fuel cells, } \\
150 \mathrm{~kW} \text { each }\end{array}$ \\
\hline Propulsion Motor & $\begin{array}{l}\text { Reuland Electric three-phase induction motor } \\
\text { rated at } 225 \mathrm{~kW}\end{array}$ \\
\hline Transmission & Six-speed automatic \\
\hline Fuel & Gaseous hydrogen \\
\hline Hydrogen Storage & $\begin{array}{l}\text { Eleven on-board, Dynetek Dynecell carbon } \\
\text { fiber-wrapped tanks }\end{array}$ \\
\hline $\begin{array}{l}\text { Emissions } \\
\text { Equipment }\end{array}$ & Zero emissions \\
\hline
\end{tabular}

A specialized maintenance structure was built at VTA's Cerone Operations Division, where the buses are based. This facility is equipped with an array of sensors and alarms, as well as specialized doors and heating. Like compressed natural gas buses, hydrogen buses require a maintenance facility with adequate ventilation and other safeguards.

\section{NOW THAT THE BUSES ARE IN REVENUE SERVICE,} the evaluation is underway. NREL is currently collecting performance and operational data on the fuel cell and baseline diesel buses. The objective of the DOE/NREL evaluation is to provide comprehensive, unbiased results of advanced technology vehicle development and operations, including economic, technical, and safety analyses. It will also assess hydrogen infrastructure development and operation and provide descriptions of facility modifications required for the safe operation of the fuel cell vehicles. Decision makers, including transit operators considering the use of these advanced technology vehicles, are the primary audience for this information.

\begin{tabular}{|c|c|}
\hline \multicolumn{2}{|c|}{ Zero-Emission Bus Program Partners } \\
\hline Company & Role \\
\hline VTA & Demonstration partner and funding \\
\hline SamTrans & Demonstration partner and funding \\
\hline Gillig & Bus manufacturer \\
\hline Ballard & $\begin{array}{l}\text { Fuel cell and propulsion system } \\
\text { manufacturer }\end{array}$ \\
\hline Air Products & Fuel and fueling facility supplier \\
\hline $\begin{array}{l}\text { Federal Transit } \\
\text { Administration }\end{array}$ & Funding \\
\hline $\begin{array}{l}\text { California Energy } \\
\text { Commission }\end{array}$ & Funding \\
\hline $\begin{array}{l}\text { Bay Area Air Quality } \\
\text { Management District } \\
\text { (BAAQMD) }\end{array}$ & Funding \\
\hline $\begin{array}{l}\text { California Fuel Cell } \\
\text { Partnership (CaFCP) }\end{array}$ & Support \\
\hline CARB & Support and regulations \\
\hline DOE/NREL & Technical evaluation \\
\hline
\end{tabular}

\section{Contacts}

Santa Clara Valley Transportation Authority Art Douwes

Phone: 408-321-7027

douwes@vta.org

National Renewable Energy Laboratory

Leslie Eudy

Phone: 303-275-4412

E-mail: leslie_eudy@nrel.gov

\section{Produced by the}

National Renewable Energy Laboratory (NREL)

NREL is a U.S. Department of Energy National Laboratory

Operated by Midwest Research Institute $\bullet$ Battelle

\section{Web Sites}

VTA: www.vta.org

SamTrans: www.samtrans.com

Ballard: www.ballard.com

Gillig: www.gillig.com

Air Products: www.airproducts.com

DOE: www.eere.energy.gov/hydrogenandfuelcells

NREL: www.nrel.gov/vehiclesandfuels/fleettest

CaFCP: www.cafcp.org

Federal Transit Administration: www.fta.dot.gov

BAAQMD: wWw.baaqmd.gov

CARB: www.arb.ca.gov
For more information contact:

EERE Information Center

1-877-EERE-INF (1-877-337-3463)

www.eere.energy.gov

A Strong Energy Portfolio for a Strong America

Energy efficiency and clean, renewable energy will mean a stronger economy, a cleaner environment, and greater energy independence for America. Working with a wide array of state, community, industry, and university partners, the U.S. Department of Energy's Office of Energy Efficiency and Renewable Energy invests in a diverse portfolio of energy technologies.

\section{DOE/G0-102005-2147 - September 2005}

Printed with a renewable-source ink on paper containing at least

$50 \%$ wastepaper, including $20 \%$ postconsumer waste. 